\title{
Retrograde Submental Intubation Assisted with Direct Video Laryngoscopy in Maxillofacial Trauma: Technical Note and Case Report
}

\author{
Intubación Submentoniana Retrógrada Asistida con Videolaringoscopía \\ en Trauma Maxilofacial: Nota Técnica y Reporte de Caso
}

Ignacio Velasco ${ }^{1} \&$ Soheil Vahdani ${ }^{2}$

VELASCO, I. \& VAHDANI, S. Retrograde submental intubation assisted with direct video laryngoscopy in maxillofacial trauma: Technical note and case report. Int. J. Odontostomat., 11(1):67-70, 2017.

ABSTRACT: The management of a difficult airway is one of the biggest challenges of perioperative anesthesia management. The maxillofacial trauma can cause serious disturbances of the soft and hard tissues of the anatomical components of the upper airway and often with little external evidence of deformity. The submental intubation is a procedure that was reported to avoid tracheostomy and allow for the concomitant restoration of occlusion and reduction of facial fractures in patients with craniomaxillofacial trauma ineligibles for nasotracheal intubation. We described a modification of the original technique by performing a retrograde submental intubation assisted by direct laryngoscope video in a maxillofacial trauma patient with restricted mouth opening. In addition, the surgical anatomy of the technique is detailed described.

KEY WORDS: submental intubation, difficult airway, maxillofacial trauma.

\section{INTRODUCTION}

The management of a difficult airway is one of the biggest challenges of perioperative anesthesia management. The maxillofacial trauma can cause serious disturbances of the soft and hard tissues of the anatomical components of the upper airway and often with little external evidence of deformity (Arya et al., 2005). Several airway management techniques have been described, including: oral intubation, nasal intubation, blind nasal intubation, fiberoptic guided nasal intubation, submental intubation and tracheostomy. Each technique has its indications with advantages and disadvantages.

The submental intubation is a procedure that was reported to avoid tracheostomy and allow for the concomitant restoration of occlusion and reduction of facial fractures in patients with craniomaxillofacial trauma, ineligible for nasotracheal intubation due to the potential risk of creating a false passage to the cranial cavity (Jundt et al., 2012). This technique was first described in 1986 by Francisco Hernandez Altemir and since its first description 10 articles have been published outlining modifications to the original technique primarily aimed at reducing complications (Altemir, 1986; Jundt et al.).

The original surgical procedure consists in the externalization of the endotracheal tube from the mouth through the floor of the mouth and the submental triangle. A skin incision of $2 \mathrm{~cm}$ in the submental, paramedian region and with blunt dissection toward the floor of mouth until the mucosa was tented with a hemostat after which another $2 \mathrm{~cm}$ incision is made in the mucosa (Fig. 1A). The breathing circuit is briefly disconnected as the tube is externalized and reconnected to the circuit and then secured to the patient (Fig. 1B).

Many features make the submental intubation very useful in several clinical scenarios including craniomaxillofacial trauma, orthognathic surgery and pathology. In a literature review conducted by Jundt et

\footnotetext{
${ }^{1}$ Former Chief Resident, Department of Oral and Maxillofacial Surgery. University of Puerto Rico. San Juan, Puerto Rico.

${ }^{2}$ Resident, Department of Oral and Maxillofacial Surgery. University of Puerto Rico. San Juan, Puerto Rico.
} 
al., it was evidenced that the technique has a $100 \%$ success, and only minor complications were reported in $7 \%$ of the 842 cases included in the study.

The main objective of this study is to describe a modification of the original technique by performing a retrograde submental intubation assisted by direct laryngoscope video in a maxillofacial trauma patient with restricted mouth opening. In addition, the surgical anatomy of the technique is described in detail.

\section{CASE REPORT}

A 29-year-old male presented to the Puerto Rico Medical Center Emergency Room with history of motor vehicle accident. On initial evaluation the patient was in non-acute distress, alert, awake and oriented, with a Glascow coma score of 15 . The patient had suffered trauma to the midface. Examination of the face revealed periorbital and nasal swelling, traumatic telecanthus, nasal deformity, epistaxis and bilateral subconjuntival hemorrhage. There was midface mobility, malocclusion and mouth opening was restricted. Further clinical examination did not reveal any other traumatic injury. Radiologic examination confirmed the presence of Le Fort II fracture, naso-orbitoethmoid fracture, bilateral zygomaticomaxillary complex fractures and left mandible subcondylar fracture.

Technique: After preoxygenation and intravenous induction of anesthesia, submental region and anterior neck is disinfected and draped as usual sterile fashion. Cricothyroid membrane was localized and marked between thyroid and cricoid cartilages, then a Raulerson syringe with a 21 caliber needle gauge was introduced at a $45^{\circ}$ cephalically through the Cricothyroid membrane into the trachea with continuous aspiration until air was aspired (Fig. 2A). Then using Seldinger technique the malleable wire (Spring-Wire Guide: $0.46 \mathrm{~mm}$ dia. x $68 \mathrm{~cm}$ length) was passed through the syringe and needle into the larynx, meanwhile the second operator performed laryngoscopy with the McGRATH ${ }^{\circledR}$ direct video laryngoscope (Medtronic, MN, USA) (Fig. 2B) to retrieve the malleable wire from posterior pharynx with a hemostat forceps and securing both ends of wire (Fig. 3A).

The appropriate reinforced endotracheal tube size was passed (which connector was previously removed) through with the malleable wire as guidance, when the distal end of the endotracheal tube meets the resistance at the level of the cricothyroid membrane (against the wire), the wire was cut at the puncture site and the endotracheal tube passed, the remaining wire removed through the tube. The endotracheal tube was secured and adequate end tidal carbon dioxide curve was observed.

Throat pack was placed. A $1.5-2 \mathrm{~cm}$ skin crease mark was made $2 \mathrm{~cm}$ from the midline and $2 \mathrm{~cm}$ below the inferior border of the mandible. Incision site was prior infiltrated with $5 \mathrm{ml}$ of xylocaine $2 \%$ with epinephrine 1:100.000 for hemostasis, then skin incision and blunt dissection was done through the topographic planes (subcutaneous fat, platysma muscle, superficial layer of deep cervical fascia, anterior belly of digastric muscle, mylohioid muscle and floor of mouth mucosa). A closed Kelly hemostatic forceps was introduced through the incision until the tip of the hemostat tented the mucosa of the floor of the mouth staying close to the lingual surface of mandible and lateral to the sublingual caruncle to avoid injury to the submandibular duct and lingual nerve. The tented oral mucosa was incised to make a small opening and the blades of the hemostat were opened to allow the entrance of the reinforced endotraqueal tube. The endotracheal tube was disconnected from the breathing circuit and the connector removed (the anesthesiologist stabilized at this moment the endotracheal tube with Magill's forceps to avoid extubation).

Afterwards the pilot balloon was grasped with the hemostat and pulled out gently through the passage, then the hemostat was reinserted through the passage to grasp the proximal end of the endotracheal tube to be brought out with controlled rotational movements. The connector and breathing system were reattached and the cuff reinflated. The endotracheal tubes now lies on the floor of the mouth between the tongue and the mandible. The anesthesiologist reassures the adequate end tidal carbon dioxide curve and auscultation of the chest for correct position of the tube. Finally, the endotracheal tube is fixed to skin with sutures to prevent accidental displacement (Fig. 3B). The open reduction and internal fixation of the facial fractures could then be performed as planned and the occlusion checked with intermaxillary fixation. At the end of the surgery the tube was disconnected, pulled back into the oral cavity and reconnected. Extraorally the wound was sutured and the patient was extubated without complications. 

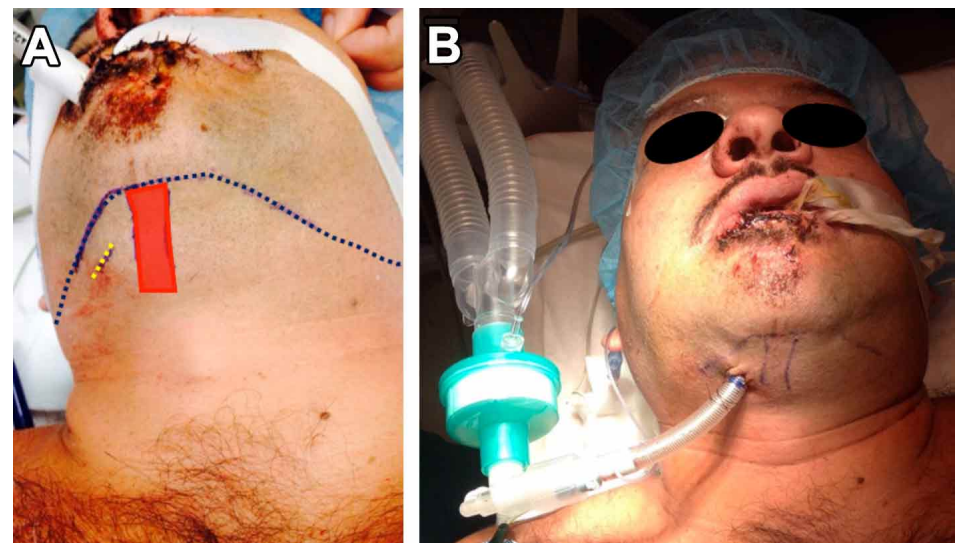

Fig. 1. Submental intubation, A. Mandible border (blue line), skin incision (yellow line), center region of geniohyoid and genioglossus muscles (red area); B. Endotracheal tube in position fixed to skin.
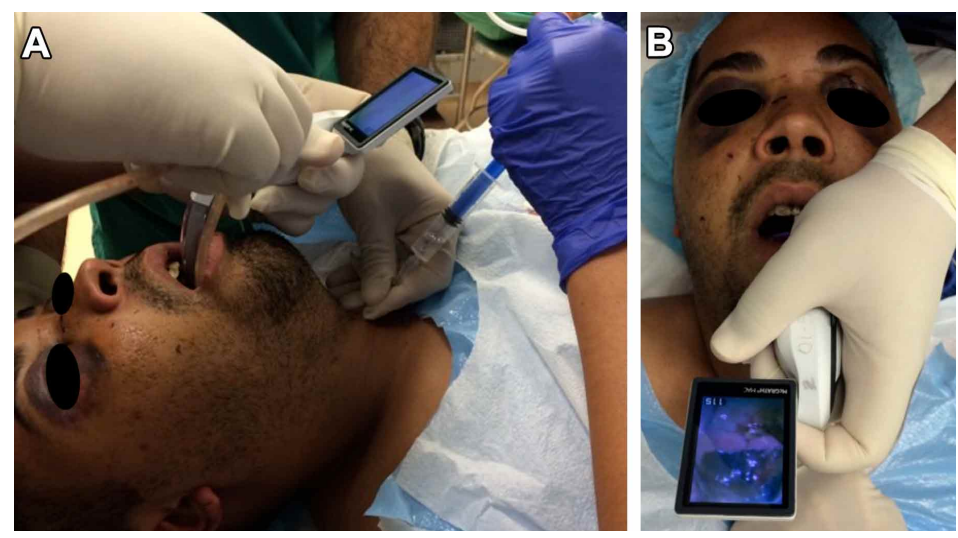

Fig. 2. A. Guide wire insertion through cricothyroid membrane; B. Direct video laryngoscopy
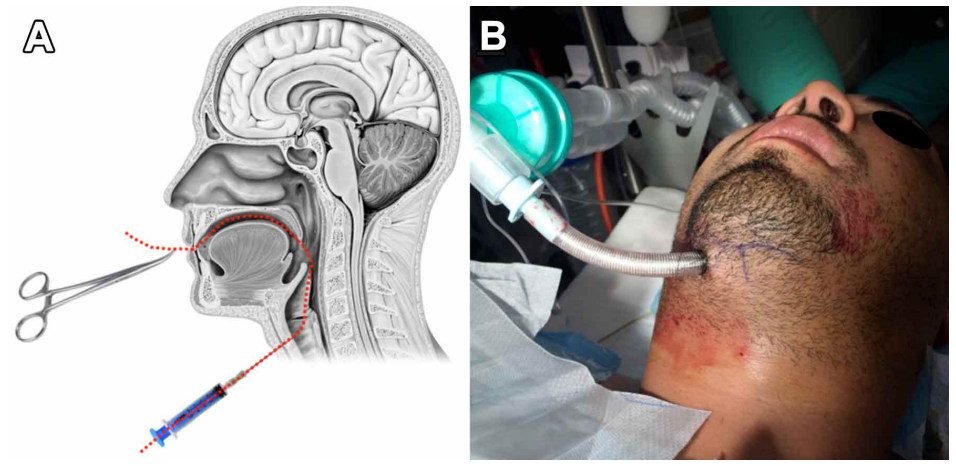

Fig. 3. A. Guide wire (red dotted line) passed through larynx to oral cavity; B. Reinforced endotracheal tube fixed to skin.

\section{DISCUSSION}

Since the first application of this technique, less than thirty years ago, many authors have studied the clinical use of this procedure. Very low rates of complications have been reported. Many trials have shown the submental route to be a simple, quick and safe approach to airway management (Caubi et al., 2008).

Submental intubation combines the advantages of nasotracheal intubation, which allows the mobilization of the dental occlusion, and those of orotracheal intubation, which allows access to nasoorbito-ethmoidal fractures (Caubi et al.). It also avoids the potential risks of iatrogenic meningitis or trauma of the anterior skull base in nasotracheal intubation cases (Junsanto \& Chira, 1997; Maclnnis \& Baig, 1999; Schade \& Borzotta, 2000).

There have been several articles in the literature describing and modifying the technique (Altemir; Jundt et al. However, adequate mouth opening is a prerequisite for the technique. Submental intubation or its modification as retrograde submental intubation was first described in a patient with restricted mouth opening by Arya et al., using a self-designed pharyngeal loop. Nevertheless, we report for the first time the retrograde submental intubation technique using direct video laryngoscopy.

It was decided to use retrograde intubation technique in the present case due to the restricted mouth opening, and the difficulty to maintain a clear airway with the submandibular incision bleeding or other invasive manipulation. The Insertion of the wire guide through the cricothyroid membrane helps to place correctly the endotracheal tube and also counting with the assistance of the direct video laryngoscopy, where the complete mouth opening is not necessary.

The limitation of this technique is for patients who also present a neurological deficit or thoracic trauma and need more than 7 days of postoperative ventilator support (Jundt et al.). In such cases a tracheostomy is the indicated procedure. In our case where the patient only presented midface isolated trauma with need of intraoperative intermaxillary fixation, submental intubation was the correct choice for intraoperative airway. 
In comparing submental intubation and tracheostomy, submental intubation has no significant reported major complications (Jundt et al.). Tracheostomy complications include hemorrhage, surgical emphysema, wound site infection, recurrent laryngeal nerve injury, tracheal stenosis, poor scar aesthetics, tracheoarterial fistula and death (Johnson, 2002 \& Jundt et al.). The mortality rate of tracheostomy has been reported to range from $0.5 \%$ to $2.7 \%$ (Zeitouni \& Kost, 1994; Jundt et al.). In addition to fewer reported minor complications (infection, fistula, hypertrophic scarring, mucocele), submental intubation requires less time than a tracheostomy, costs less and results in an aesthetically well tolerated scar (Jundt et al.).

In conclusion, submental intubation is a safe and effective technique for establishing a secure airway in patients requiring facial reconstructive surgery where traditional oral and nasotracheal intubation are contraindicated. Additional research is necessary to validate new modifications reported in the literature. In choosing a potential modification, the surgeon should inform the anesthesiologist of their intended sequence. Communication between the surgeon and anesthesiologist is extremely important for the safety of the patient and the success of the procedure.

VELASCO, I. \& VAHDANI, S. Intubación submentoniana retrógrada asistida con videolaringoscopia en trauma maxilofacial: nota técnica y reporte de caso. Int. J. Odontostomat., 11(1):61-65, 2017.

RESUMEN: El manejo de una vía aérea difícil es uno de los mayores desafíos del manejo anestésico perioperatorio. El trauma maxilofacial puede causar serias alteraciones a los tejidos blandos y duros de la vía aérea superior, y muchas veces con pequeña evidencia externa de deformidad. La intubación submentoniana es un procedimiento que fue reportado para evitar la traqueostomía y permitir la concomitante restauración de la oclusión para la reducción de fracturas faciales en pacientes donde la intubación nasotraqueal está contraindicada. Describimos una modificación de la técnica original, realizando una intubación submentoniana retrógrada asistida con videolaringoscopio en un paciente de trauma maxilofacial con apertura de la cavidad disminuida. Adicionalmente se describe detalladamente la anatomía quirúrgica de la técnica.

PALABRAS CLAVE: intubación submentoniana, vía aérea difícil, trauma maxilofacial.

\section{REFERENCES}

Altemir, F. H. The submental route for endo-tracheal intubation. A new technique. J. Maxillofac. Surg., 14:64-5, 1986.

Arya, V. K.; Kumar, A.; Makkar, S. S. \& Sharma, R. K. Retrograde submental intubation by pharyngeal loop technique in a patient with faciomaxillary trauma and restricted mouth opening. Anesth. Analg., 100(2):534-7, 2005.

Caubi, A. F.; Vasconcelos, B. C.; Vasconcellos, R. J.; de Morais, H. H. \& Rocha, N. S. Submental intubation in oral maxillofacial surgery: review of the literature and analysis of 13 cases. Med. Oral Patol. Oral Cir. Bucal., 13(3):197-200, 2008.

Johnson, T. R. Submental intubation versus tracheostomy. Br. J. Anaesth., 89(2):344-5, 2002.

Jundt, J. S.; Cattano, D.; Hagberg, C. A. \& Wilson, J. W. Submental intubation: a literature review. Int. J. Oral Maxillofac. Surg., 41(1):46-54, 2012.

Junsanto, T. \& Chira, T. Perimortem intracranial orogastric tube in pediatric trauma patient with a basilar skull fracture. J. Trauma. 42(4):746-7, 1997.

Maclnnis, E. \& Baig, M. A. modified submental approach for oral endotracheal intubation. Int. J. Oral Maxillofac. Surg., 28(5):3446, 1999.

Schade, K.; Borzotta, A. \& Michaels, A. Intracranial malposition of nasopharyngeal airway. J. Trauma., 49(5):967-8, 2000.

Zeitouni, A. G. \& Kost, L. M. Tracheostomy: a retrospective review of 281 cases. J. Otolaryngol., 23(1):61-6, 1994.

Corresponding author:

Dr. Ignacio A. Velasco

Av. Pasaje Republica de Honduras interior 12.279.

Santiago

CHILE

Email: ignacio.velasco@upr.edu

Received: 05-09-2016

Accepted: 23-12-2016 